\title{
Molecular distributions of phospholipid ester-linked fatty acids in a soil profile of the Dinghushan Biosphere Reserve
}

\author{
Shengyi Mao ${ }^{1}$, Yongge Sun ${ }^{2, *}$, Deqiang Zhang ${ }^{3}$, Juxiu Liu ${ }^{3}$, and Guoyi Zhou ${ }^{3}$ \\ ${ }^{I}$ Key laboratory of Gas Hydrate, Guangzhou Institute of Energy Conversion, Chinese Academy of Sciences, Guangzhou, China \\ ${ }^{2}$ Department of Earth Science, Zhejiang University, Hangzhou, China \\ ${ }^{3}$ Key Laboratory of Vegetation Restoration and Management of Degraded Ecosystems, South China Botanical Garden, Chinese \\ Academy of Sciences, Guangzhou, China
}

Article history:

Received 9 August 2016

Revised 7 August 2017

Accepted 6 October 2017

Keywords:

Phospholipid ester-linked fatty acids, Dinghushan Biosphere Reserve,

Carbon accumulation

Citation:

Mao, S., Y. Sun, D. Zhang, J. Liu, and G. Zhou, 2018: Molecular distributions of phospholipid ester-linked fatty acids in a soil profile of the Dinghushan Biosphere Reserve. Terr. Atmos. Ocean. Sci., 29, 275-290, doi: 10.3319/TAO.2017.10.06.03

\begin{abstract}
Phospholipid ester-linked fatty acids (PLFA) were used to investigate the microbial ecology and its association with carbon accumulation in one soil profile from the Dinghushan Biosphere Preserve in south China, in order to probe the mechanisms that control the carbon accumulation at the depth of $0-20 \mathrm{~cm}$ in the Dinghushan forest soil profile. The data show that sulfate reducing bacteria (SRB) occur in the top 10 $\mathrm{cm}$, and methanotrophic bacteria and fungi are not present below $10 \mathrm{~cm}$, and the gramnegative bacteria are reduced with gram-positive bacteria dominating at that depth; all of which indicated that the activities of some of the microorganisms were inhibited, from which we infer that the available carbon source and oxygen content of micro environment may be reduced below $10 \mathrm{~cm}$ of the profile. The shallow depth (top 10 $\mathrm{cm}$ ) of the soil anaerobic zone at the Wukesong profile, compared to the normal soil anaerobic zone (top $20-30 \mathrm{~cm}$ ), is considered to be mainly the result of the high precipitation of acidic rain. The physicochemical reactions caused by acid rain in the soil system result in a decreased soil porosity, and a correspondingly decreased porositydependent oxygen concentration, leading to the thriving of SRB in the shallow depth. Although the increase of soil organic carbon stock is attributed to numerous factors, the decreasing rate of litter decomposition in the topsoil layer, together with the rise of the depth of the anaerobic zone, may play key roles in the carbon accumulation in the depth of $0-20 \mathrm{~cm}$ in the soil profile from the Dinghushan Biosphere Preserve.
\end{abstract}

\section{INTRODUCTION}

The increase of $\mathrm{CO}_{2}$ concentration in the atmosphere leads to the rise of temperature, which is the focus of global climate change and global carbon cycle research. In the past few decades, the research of terrestrial ecosystem carbon cycle has been progressing rapidly, but the global "missing carbon sink", in that of the global carbon released, approximately $1 / 3$ disappears without a trace, has yet to be resolved by the scientific community. In the carbon cycle, the actual carbon increment in the atmosphere, the actual carbon increment absorbed by the ocean and the total increment of fossil fuel are relatively easy to measure accurately, so the carbon increment of land use change in the world is likely the key to the "missing carbon sink". However, the variety

\footnotetext{
* Corresponding author

E-mail:ygsun@zju.edu.cn
}

of types of terrestrial ecosystems, large carbon cycle temporal variability, and the weak current carbon cycle research, introduce much uncertainty and many problems to current incremental evaluations of land use change (Bazzaz 1990; Koch and Mooney 1996).

In the global terrestrial ecosystem, soil organic carbon (SOC) accounts for approximately $2 / 3$ of the total terrestrial carbon, which is approximately 2 times the total carbon content of the atmosphere, and 4 times of that of the vegetation carbon pool. The amount of carbon exchange between the soil and the atmosphere is $60 \mathrm{PgC} \mathrm{yr}^{-1}$, which is ten times that of the global fossil fuel release (Fernandez et al. 1993). The terrestrial ecosystem of soil organic carbon undergoing only relatively minor changes will lead to great changes of the soil organic carbon pool in absolute amounts, and can cause the atmospheric carbon exchange to be intensified, 
which would then eventually contribute to global climate change. Therefore, it is of practical significance to study the mechanism and controlling factors of soil carbon accumulation if we are to reduce the concentration of atmospheric $\mathrm{CO}_{2}$ via the current international discussion of "carbon emissions". As the main body of the terrestrial ecosystem, forest area accounted for $34 \%$ of the global land, and its ecosystem carbon reserves accounted for $77 \%$ of the total global terrestrial carbon pool, while its soil organic carbon accounted for $73 \%$ of the global forest soil organic carbon pool (Guan 1989; Eswaran et al. 1993). Therefore, the forest soil organic carbon storage mechanism plays an important role in the carbon cycle of terrestrial ecosystems.

Because the forest occupies a leading position in the terrestrial ecosystem, in-depth analysis of forest carbon cycle plays an important role in reducing the uncertainty of the terrestrial carbon cycle, and carbon cycle research in different regions of the typical forest ecosystem has become an important area of recent research. According to the traditional theory, the more mature the forest ecosystem, the smaller the net productivity. The net productivity of some zonal forests is almost zero, and even negative growth or fluctuation can occur in certain periods of time (Schimel et al. 2001). Therefore, it is believed that with the vegetation restoration and succession, the more mature forests have less of an impact on the global carbon balance, and finally disappear. Because of those characteristics of mature forest ecosystems, in the search for the whereabouts of the global sinks of carbon, the effect of mature forest ecosystems on carbon balance is often ignored. However, through continuous determination of soil carbon storage in monsoon evergreen broad-leaved forest for nearly 30 years, recently Southern China Institute of Botany, CAS found in South Subtropical zonal forest, soil carbon increased at the rate of $0.61 \mathrm{t} \mathrm{hm}^{-2}(0-20 \mathrm{~cm}$ and mineral soil) and $3.83 \mathrm{t} \mathrm{hm}^{-2}$ (including litter layer below the soil layer, Zhou et al. 2006). This phenomenon is also found in the European carbon cycle observation platform (Luyssaert et al. 2008). The abnormal findings about mature forest ecosystem carbon accumulation provide a new way for revealing the global terrestrial carbon sink, and at the same time, the mature forest ecosystem carbon accumulation mechanism and control factors have become the major scientific problems.

There are many factors controlling the soil organic carbon (SOC) accumulation, including the litter quality, nutrient conditions, soil characteristics, temperature, soil wet-dry cycle, $\mathrm{pH}$, nitrogen deposition, $\mathrm{CO}_{2}$, microbial communities, etc. (Clein and Schimel 1994; Motavalli et al. 1995; Six et al. 1999; Giardina and Ryan 2000; Hobbie and Vitousek 2000; Krajick 2001). The recent focus has been on the dynamic response of the microbial community composition and activity in the soil to variable environmental conditions (Schutter and Dick 2001; McKinley et al. 2005; Kanerva et al. 2008; Franklin and Mills 2009; Budge et al. 2011;
Nguyen et al. 2011; Wang et al. 2012). A previous study has shown that the microbial community can play a key role in the biogeochemical cycles and the metabolic processes of soil organics, which have direct effects on the accumulation of soil organic matter (Giardina and Ryan 2000). The most important process involved in the SOC accumulation is the dynamics of microbial decomposition that is primarily constrained by the biomass and characteristics of the soil microbial community. Due to abundant fresh organic inputs and the oxygen-exposed environment, the biomass content and structural diversity of the microbial community in the top soil layer are both high, which explains the rapid decomposition of most of the organic matter that occurs in this layer (Fierer et al. 2003; Castellazzi et al. 2004). As such, the final SOC accumulation mainly depends on the extent of decomposition by microbes in the top layer of soil in a given ecosystem. In other words, SOC accumulation is dependent on the activity and structural diversity of the microbial community. Theoretically, the identification of the redox transition zone in the soil profile, together with a significant decrease of biomass, could be indicators for the occurrence of stable SOC.

Most soil microorganisms cannot be characterized by conventional cultivation techniques (Amann et al. 1995; Zelles et al. 1997). Up to now, there are two methods that are commonly used to overcome the problem of selective culturing while providing an unbiased view of the structure of complex microbial communities. One is the ribosomal RNA technology used to examine microbial populations. Another is phospholipid fatty acid (PLFA) analysis (Findlay et al. 1996). In the present study, the possibility of using PLFA analysis to differentiate groups of microorganisms and their biomass in the soil is investigated, since analysis of phospholipids within soil provides a means with which to link the activity and structural diversity of the microbial community with the processes involved in the decomposition of SOC during burial.

Phospholipids are integral components of cell membranes and are composed of a hydrophilic glycerophosphate headgroup and two nonpolar fatty acid-derived tails, and can be a sound indication of living cells at the time of sampling. The phospholipid ester-linked fatty acids (PLFA) in modern soils and sediments arise mainly from the live cell membranes of the microbes, plankton, higher plants, and animalcules, etc. (Lechevalier and Moss 1977). PLFAs can be used to represent the soil microbial community, including the predominant microbes that cannot be cultured (Zelles et al. 1997). The total phospholipid abundance can provide a proxy for viable biomass (White et al. 1979; Baird and White 1985; Baird et al. 1985), and the distribution of phospholipid ester-linked fatty acids can be used to distinguish structures of the microbial community in soils or sediments (Kaneda 1967; Balkwill et al. 1988; Paul and Clark 1996). For example, the concentration of n16:0 PLFA is 
usually used as a biomarker to evaluate the total biomass of microbial populations in a sample, due to its wide distribution in all groups of microbes. While the 10me16:0 PLFA is mostly derived from actinomycetes, planctomycetes, and sulfate-reducing bacteria, of which the latter two are both anaerobes (Kroppenstedt 1985; Sittig and Schlesner 1993; Stoeck et al. 2002). Introduction of compound-specific carbon isotopic analysis of PLFA can yield information on carbon pathways within microbial communities (Abraham et al. 1998; Boschker et al. 1998, 1999) which in turn can be linked to information provided by lipid distributions about the types and abundances of microorganisms.

To date, for the mechanism controlling the SOC increase within the upper $20 \mathrm{~cm}$ of soil in the Dinghushan Biosphere Preserve is still unknown. In this study, both the distribution of PLFA in soils and its stable carbon isotopic compositions were measured for soils of the Dinghushan Biosphere Preserve in south China. The mature forest in the preserve is well developed and has rarely been disturbed by anthropogenic activities. The aims of this study are to (1) characterize the dynamics of the microbial community and structural diversity in the soil profile from the mature forest in the Dinghushan Biosphere Preserve using PLFA biomarkers; (2) determine the transition zone from aerobic to anaerobic environments in the soil profile using specific PLFA distributions and their stable carbon isotopic compositions.

\section{SAMPLE BACKGROUND}

The soil profile for this study was collected from the Dinghushan Biosphere Preserve, south China (Fig. 1). The Dinghushan Biosphere Preserve is located in the central part of Guangdong Province of south China, in a northeastern suburb of Zhaoqing city, approximately $84 \mathrm{~km}$ away from Guangzhou at $112^{\circ} 30^{\prime} 39^{\prime \prime}-112^{\circ} 33^{\prime} 41^{\prime \prime E}$ and $23^{\circ} 09^{\prime} 21^{\prime \prime}$ $23^{\circ} 11^{\prime} 30^{\prime \prime N}$. It occupies $1133 \mathrm{~km}^{2}$ covered mostly by hills and valleys. The altitude of the preserve ranges from 100 $-700 \mathrm{~m}$ above sea level, with the highest point of $1000.3 \mathrm{~m}$ at Jilongshan.

The Dinghushan Biosphere Reserve was established in 1950 to protect a remnant of undisturbed natural monsoon evergreen broadleaf forests in the subtropics and was accepted as the first Man and Biosphere Reserve in China in 1978. This Reserve shares the typical monsoonal climate, with the annual average precipitation of $1927 \mathrm{~mm}$, of which nearly $70 \%$ falls from April to September. The annual mean temperature is $21.4^{\circ} \mathrm{C}$, with the minimum of $-0.2^{\circ} \mathrm{C}$ in January, and the maximum of $38^{\circ} \mathrm{C}$ in July. The mean relative humidity is $80 \%$.

The soil in the Dinghushan Biosphere Preserve is composed mainly of lateritic red earth and mountain yellowbrown earth in vertical distribution. The lateritic red earth occurs in hilly land below an altitude of $300 \mathrm{~m}$; it is also distributed in hills and low mountains at altitudes of $300-900 \mathrm{~m}$ above sea level; the mountain yellow-brown earth occurs partially on the tops of the overlying hills. The sampling site is at the Wukesong with an altitude of $300 \mathrm{~m}$ (Fig. 1). The forest system at the Wukesong is now at the later stage of the alternative evolution of the mixed coniferous broadleaved forest where the dominant tree species include Schima superb, Castanopsis chinensis, and Pinus massoniana. The profile of the soil in downward transition to the bottom crust of weathering is $50 \mathrm{~cm}$ thick. At a depth of $0-10 \mathrm{~cm}$ is brown soil that is rich in grass roots. At a depth of 10 - $20 \mathrm{~cm}$ is the transition layer of the yellow-brown soil, where the content of sand increases obviously. At a depth of $20-50 \mathrm{~cm}$ is the brown-yellow soil layer that contains gray-white sand spots. In this profile, $1-2 \mathrm{~kg}$ samples were collected every $2 \mathrm{~cm}$ with all of the plant scraps, roots and rocks picked out, and then packaged with sterilized aluminum foil paper and directly transported to the laboratory to be frozen and dried at $-50^{\circ} \mathrm{C}$. The sample was later ground to 80 mesh with an agate grinder and kept in bags for further measurements in a freezer at $-20^{\circ} \mathrm{C}$.

\section{EXPERIMENTAL}

\subsection{TOC, $\delta^{13} \mathrm{C}_{\mathrm{TOC}}$ Analysis and pH Measurement}

The powdered samples were processed with $5 \% \mathrm{HCl}$ to remove carbonate for stable organic carbon isotopic measurements and total organic carbon analysis at State Key Laboratory of Organic Geochemistry, Guangzhou Institute of Geochemistry, Chinese Academy of Sciences. Contents of total organic carbon (TOC) were determined using a LecoC230. The $\delta^{13} \mathrm{C}_{\text {TOC }}$ was measured with a CE EA1112 $\mathrm{C} / \mathrm{N} / \mathrm{S}$ Analyzer-DELTA Plus ${ }^{\mathrm{XL}}$. The isotope values were calibrated against the reference gas and are reported in the conventional "delta" notation relative to VPDB. Analytical reproducibility for duplicate runs was better than $\pm 0.5 \%$. The $\mathrm{pH}$ value was measured by using a DELTA $320 \mathrm{pH}$ meter with a METTLER glass electrode 530, for which the instrumental accuracy is $0.01 \mathrm{pH}$.

\subsection{Lipid Extraction and Separation}

All glassware used for lipid analysis was meticulously washed, rinsed, and heated in a clean muffle furnace for a minimum of 6 hours at $450^{\circ} \mathrm{C}$. Items that will not tolerate heating to $450^{\circ} \mathrm{C}$ were rinsed with methanol followed by chloroform and were then allowed to dry. Samples were lyophilized and thoroughly homogenized using a mortar and pestle before extraction. Total lipids were extracted from samples using a modified Bligh-Dyer method (Bligh and Dyer 1959). Briefly, weighed samples were transferred to a centrifuge bottle with added chloroform/methanol/potassium phosphate buffer $(1: 2: 0.8$ by volume at $\mathrm{pH}=7.4)$, sonicated and centrifuged to separate sample from solvent. Samples were sonicated for no more than $2 \mathrm{~min}$. Once the extraction 
was complete, the bottles were centrifuged (30 min at 2000 $\mathrm{rpm}$ ) to separate sediment from solvent, and the chloroform/ methanol/potassium phosphate buffer was decanted into a separatory funnel. The concentrated total lipids were fractionated on solid phase extraction cartridges packed with silica and preconditioned with $\mathrm{CHCl}_{3}$. A suitable column was constructed by wetting the glass wool in the bottom of the pipette with ammonium acetate in methanol and transferring a silicic acid slurry $(0.5 \mathrm{~g}$ silicic acid suspended in $5 \mathrm{ml}$ $0.02 \mathrm{M}$ ammonium acetate in methanol) by Pasteur pipette. Once the procedure had begun, the packing was not allowed to dry, nor was the surface of the bed disturbed. Neutral lipids were eluted with $5 \mathrm{ml} \mathrm{CHCl}_{3}$, glycolipids were eluted with $5 \mathrm{ml}$ acetone, and phospholipids were eluted with $10 \mathrm{ml}$ methanol. Fatty acid methyl esters (FAMEs) were released from the phospholipid fraction using mild alkaline methanolysis (White et al. 1979). The positions of double bonds in monounsaturated fatty acid methyl esters were determined by gas chromatography/mass spectrometry of the dimethyl disulfide adduct.

\subsection{Gas Chromatography}

The FAMEs fraction was analyzed on an Agilent $6890 \mathrm{~N}$ gas chromatograph equipped with a $50 \mathrm{~m} \times 0.32 \mathrm{~mm}$ i.d. fused silica capillary column that was coated with a $0.25 \mu \mathrm{m}$ film of HP-5MS. The measurements were carried out using an FID (flame ionization detector) and a splitless injector system. Nitrogen was used as the carrier gas at a flow rate of $1.0 \mathrm{ml} \mathrm{min}^{-1}$. The oven temperature program started at $60^{\circ} \mathrm{C}$, followed by heating at a rate of $30^{\circ} \mathrm{C} \mathrm{min}^{-1}$ to $110^{\circ} \mathrm{C}$, and then heating at a rate of $2^{\circ} \mathrm{C} \mathrm{min}^{-1}$ to $220^{\circ} \mathrm{C}$; finally heating at a rate of $10^{\circ} \mathrm{C} \mathrm{min}^{-1}$ to $295^{\circ} \mathrm{C}$, and held for 20 min. Individual FAMEs for each sample were quantified by adding an internal standard n19:0 FAME (NuchekPrep, Elysian, MN, USA).

\subsection{Gas Chromatography-Mass Spectrometry}

FAMEs were identified by GC/MS using a Thermo Scientific DSQ II mass spectrometer coupled to a Thermo Scientific Trace gas chromatograph. Chromatographic separation was achieved with a J\&W DB-5MS $(50 \mathrm{~m} \times 0.25 \mathrm{~mm}$ id $\times$ $0.25 \mu \mathrm{m}$ ) fused silica capillary column. The oven temperature program was the same as the GC program. Helium was used as the carrier gas at a flow rate of $1 \mathrm{ml} \mathrm{min}$. The ion source temperature was $250^{\circ} \mathrm{C}$, and the ion source was operated in the electron ionization (EI) mode at $70 \mathrm{eV}$. Full scanning and the selected ion monitoring (SIM) modes were used simultaneously. FAMEs were identified by mass spectra, relative retention times and comparison with published data.

\subsection{Gas Chromatography-Isotope Ratio Mass Spectrometry}

The analysis of stable carbon isotopic compositions of

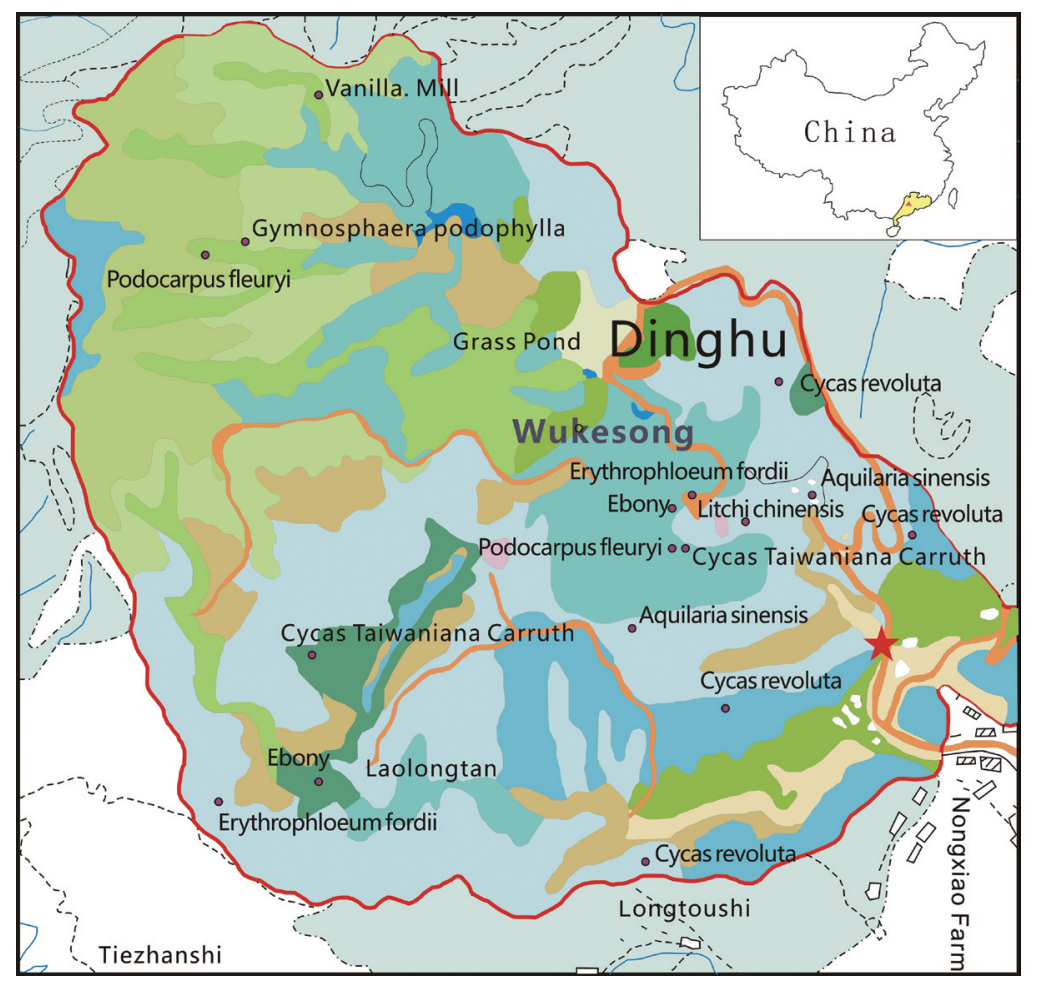

Fig. 1. Sketch map showing the location of the Dinghushan Biosphere Preserve, south China. 
individual FAMEs was performed using an Agilent 6890N gas chromatograph interfaced to a GV IsoPrime system. The GC was equipped with a $50 \mathrm{~m} \times 0.25 \mathrm{~mm}$ i.d. fused silica capillary column that was coated with a $0.25 \mu \mathrm{m}$ film of DB-5MS, which led directly into the combustion interface. The oven temperature program started at $100^{\circ} \mathrm{C}$, followed by heating at a rate of $20^{\circ} \mathrm{C} \mathrm{min}{ }^{-1}$ to $160^{\circ} \mathrm{C}$, then heating at a rate of $1.5^{\circ} \mathrm{C} \mathrm{min}^{-1}$ to $220^{\circ} \mathrm{C}$, and finally, heating at a rate of $10^{\circ} \mathrm{C} \mathrm{m^{-1 }}$ to $295^{\circ} \mathrm{C}$, and held for $20 \mathrm{~min}$. Helium was used as the carrier gas with a flow rate of $1.5 \mathrm{ml} \mathrm{min}^{-1}$. The injection of samples was conducted in the splitless mode. The combustion furnace was operated at $800^{\circ} \mathrm{C}$ and loaded with $\mathrm{CuO}$ and $\mathrm{Pt}$ wires as oxidant and catalyst, respectively. For calibration, a $\mathrm{CO}_{2}$ reference gas, which is calibrated against the Charcoal Black (a national calibrated standard, with a value of $-22.43 \%$ based on the VPDB standard), was automatically introduced into the IRMS in a series of pulses before and after the array of peaks of interest. The isotope values were calibrated against the reference gas and are reported in the typical "delta" notation relative to VPDB.

The reported $\delta^{13} \mathrm{C}$ values represent averages of $2-4$ analyses, with $< \pm 0.5 \%$ o standard deviation; the values have been corrected for the contribution from the methylating reagent (methanol) using the following equation:

$\delta^{13} \mathrm{C}_{\mathrm{FA}}=\left[\left(\mathrm{C}_{\mathrm{n}+1}\right) \delta^{13} \mathrm{C}_{\mathrm{FAME}}-\delta^{13} \mathrm{C}_{\mathrm{MeOH}}\right] / \mathrm{C}_{\mathrm{n}}$

where $\delta^{13} \mathrm{C}_{\mathrm{FA}}$ is the $\delta^{13} \mathrm{C}$ of the fatty acid, $\mathrm{C}_{\mathrm{n}}$ is the number of carbons in the fatty acid, $\delta^{13} \mathrm{C}_{\mathrm{FAME}}$ is the $\delta^{13} \mathrm{C}$ of the methylated fatty acid, and $\delta^{13} \mathrm{C}_{\mathrm{MeOH}}$ is the $\delta^{13} \mathrm{C}$ of the methanol used for the methylation reaction.

\subsection{PLFA Nomenclature}

Fatty acid nomenclature is in the form of ' $A: B \omega C$ ', where ' $A$ ' designates the total number of carbons, ' $B$ ' designates the number of double bonds, and ' $\mathrm{C}$ ' designates the number of carbons between the closest site of unsaturation and the aliphatic end of the molecule. The suffixes ' $c$ ' for cis and ' $\mathrm{t}$ ' for trans refer to geometric isomers. The prefixes ' $\mathrm{i}$ ' ' $\mathrm{a}$ ' 'cyc' 'me' and 'br' refer to iso and anteiso methyl branching, cyclopropyl branching, mid-chain methyl branching, and the methyl branch position not determined, respectively.

\section{RESULTS AND DISCUSSION}

\subsection{Bulk Soil Characteristics of Soil Organic Matter Within Soil Profile from the Dinghushan Biosphere Reserve}

The TOC content on the top layer of the soil profile from the Wukesong, Dinghushan Biosphere Reserve is the highest, followed by a quick decrease downward to a depth of $10 \mathrm{~cm}$ below the surface (Fig. 2a and Table 1). Although the TOC content still shows a decreasing trend from the top $10 \mathrm{~cm}$ to the bottom in the profile, the gradient is very slight. The largest variability of TOC contents occurs within the (a)

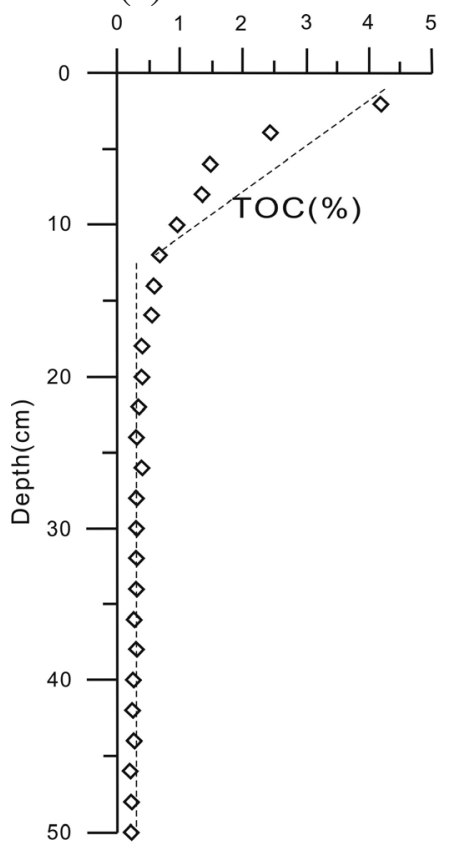

(b)

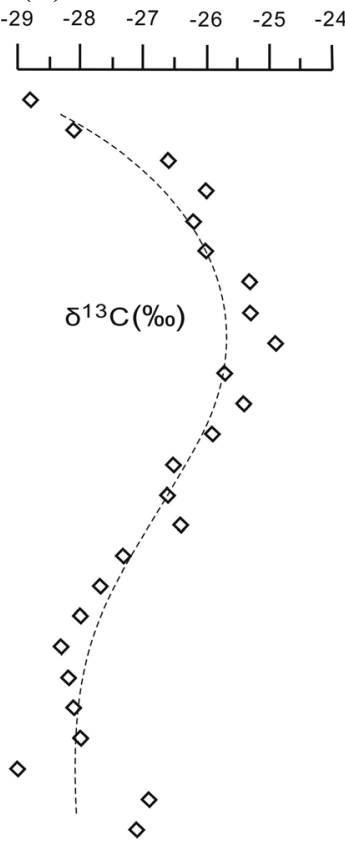

(c)

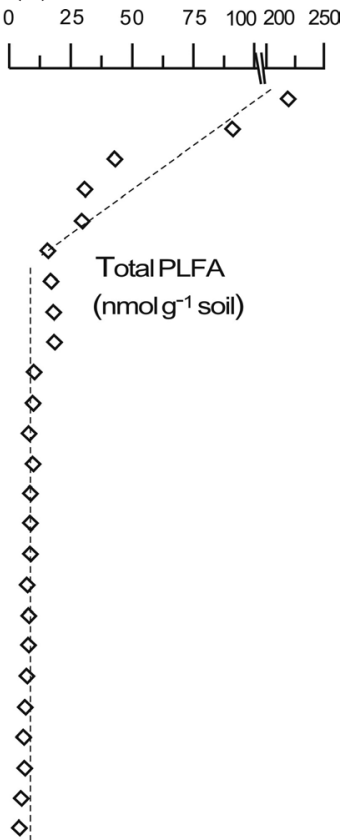

Fig. 2. The (a) TOC (\%), (b) $\delta 13 \mathrm{C}(\%)$, (c) total PLFA concentrations (nmol g-1* soil) with depth in a soil profile from the Dinghushan Biosphere Preserve. 


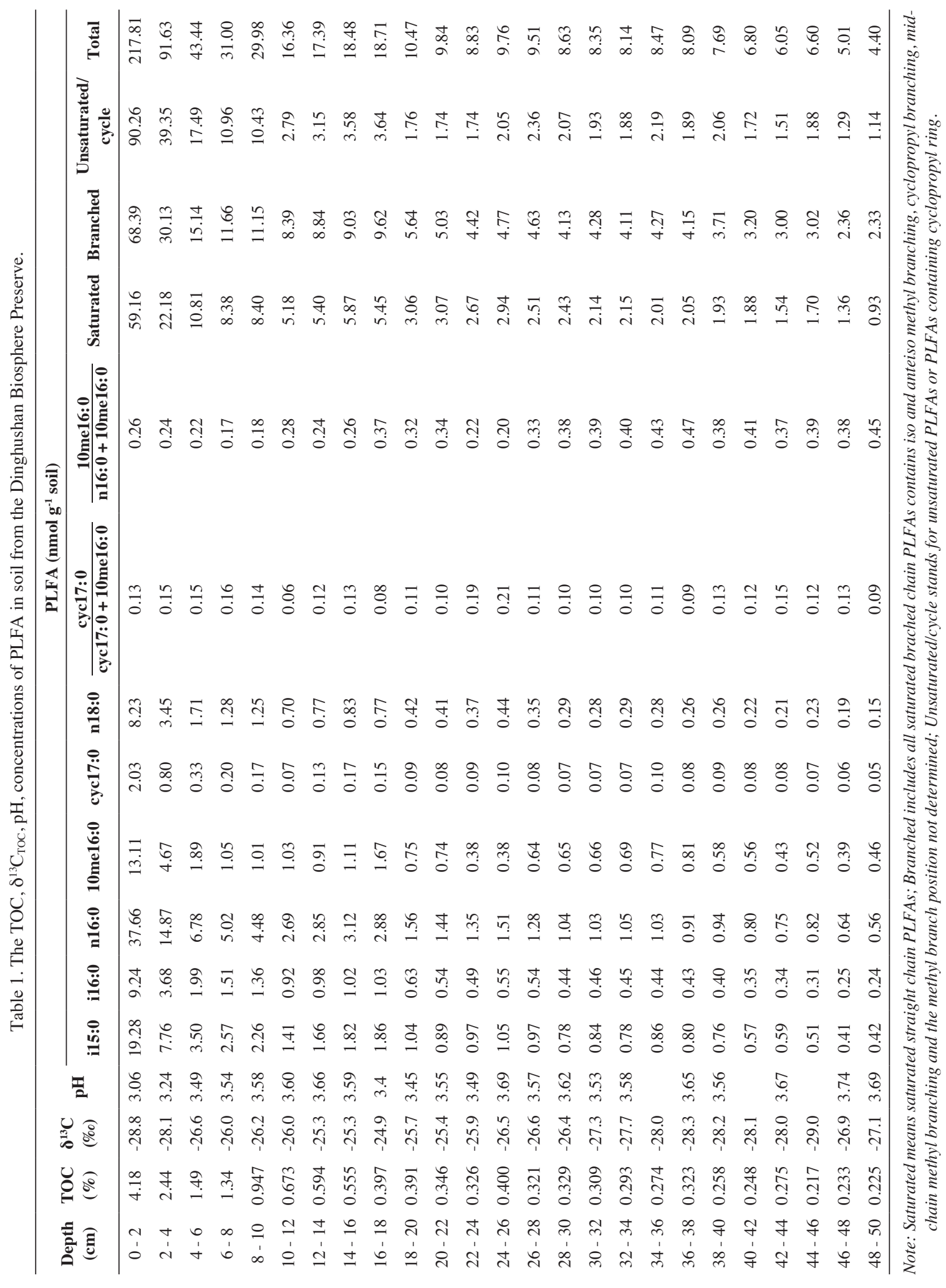


upper $10 \mathrm{~cm}$, indicating that the major consumption and/ or degradation of organic matter occurs at this depth. This result is in agreement with the previous study on the characteristics of the total organic content distribution in the soil profiles collected from all altitudes in the Dinghushan Biosphere Preserve (Chen et al. 2005), and it is also consistent with most of the published results around the world (e.g., Jenkinson and Rayner 1977; Scharpenseel et al. 1989).

The $\delta^{13} \mathrm{C}$ values of total organic matter from the soil profile range from $-29.4 \%$ to $-24.9 \%$ (Table 1, Fig. $2 b$ ). The $\delta^{13} \mathrm{C}$ value of SOC strongly depends on the organic source and physicochemical processes involved in the soil development. The Dinghushan Biosphere preserve is mainly composed of undisturbed natural monsoon evergreen broadleaved forest in the subtropics and contains predominantly $\mathrm{C}_{3}$ plants. Because there is almost no stable carbon isotopic fractionation during the early decomposition of plant litter in the surface soil layer (Balesdent et al. 1993), with a $\delta^{13} \mathrm{C}$ of $-29.4 \%$ of SOC from the litter layer at the top, it could be an indicator of $\mathrm{C}_{3}$ plants. With increasing depth, the input of organic matter is decreased and most of the organic matter is from the root exudates and autotrophic microbes that combine organic matter and other materials from the topsoil, and microbial activity starts to play an important role on the stable carbon isotopic fractionation. Due to the differences in bond energy between ${ }^{12} \mathrm{C}-{ }^{12} \mathrm{C}$ and ${ }^{13} \mathrm{C}-{ }^{13} \mathrm{C}$, purely ${ }^{12} \mathrm{C}$-containing organics are preferentially utilized by the microbes over the ${ }^{13} \mathrm{C}$-containing organics (Balesdent et al. 1993; Ågren et al. 1996; Sun et al. 2005). The ${ }^{12} \mathrm{C}$-containing organics are thus decomposed before the ${ }^{13} \mathrm{C}$-contained organics. Most of the ${ }^{12} \mathrm{C}$-containing organics are reduced to $\mathrm{CO}_{2}$ that escaped out of the soil, leading to a rapid increase of the $\delta^{13} \mathrm{C}_{\mathrm{TOC}}$ value of the soil organic matter. As shown in Fig. $2 \mathrm{~b}$, the $\delta^{13} \mathrm{C}_{\text {Tос }}$ value gradually increases up to a maximum at a depth of approximately $15-20 \mathrm{~cm}$. However, below this depth, the $\delta^{13} \mathrm{C}$ values of SOC at a depth of $20-40 \mathrm{~cm}$ show a trend of the opposite direction with ${ }^{12} \mathrm{C}$ enrichment in SOC. One possibility is that the decrease of ${ }^{12} \mathrm{C}$ organics is caused by microbes which consume ${ }^{12} \mathrm{C}$ faster than ${ }^{13} \mathrm{C}$ in the deep buried soil layer as revealed by TOC contents (Fig. 2a), and so the substrate becomes mainly composed of heavier $\delta^{13} \mathrm{C}$ organics. Then, when the utilization rate of ${ }^{13} \mathrm{C}$-containing organics caught up with and even surpassed the ${ }^{12} \mathrm{C}$-containing organics' by the microbial community in the deep buried soil layer possibly results in an enrichment of ${ }^{12} \mathrm{C}$ in SOC. The $\delta^{13} \mathrm{C}_{\mathrm{TOC}}$ value finally reaches a relatively stable level at a depth of $40-50 \mathrm{~cm}$ (Fig. 2b), possibly indicating the formation of recalcitrant soil organic matter.

\subsection{Molecular Distributions of PLFA with Soil Depth from the Dinghushan Biosphere Reserve}

PLFA in recent sediments are mainly from the living cell membranes of the microbes, plankton, higher plants, and animalcules, etc. (Lechevalier and Moss 1977). Due to the removal of roots and organisms living in the soil during sample preparation, the absence of long-chain $\left(>\mathrm{C}_{25}\right)$ FAMEs in the chromatograms strongly suggests that the contribution of higher living organisms is negligible (Fig. 3). Therefore, the majority of the PLFA detected in the soil from the Wukesong in the Dinghushan Biosphere Preserve are derived from bacteria.

A previous study showed that the biomass in the soils and sediments presented by PLFA method is consistent with the data obtained by the cell wall acid method, ATP method, and acridine orange direct counting method, with a little standard deviation (Balkwill et al. 1988). The soil microbe biomass, as revealed by the total concentration of PLFA in the soil profile at the Wukesong, ranges from 4.40 $217.81 \mathrm{nmol} \mathrm{g}^{-1}$ soil, showing a similar trend with TOC content. The highest biomass occurs at the top of the profile (217.81 $\mathrm{nmol} \mathrm{g}{ }^{-1}$ soil) followed by a quick decrease to the depth of top $20 \mathrm{~cm}$, and then the total content of PLFA remains relatively stable to the bottom of profile (Fig. 2c). The total PLFA concentrations are highly correlated to the TOC data with a correlation coefficient of 0.95 (Fig. 4), indicating that activity of the microbes is significantly controlled by the input of the organic matter in the soil.

The carbon number distribution of the PLFA detected in the 25 soil samples ranges from $C_{15}$ to $C_{20}$ and is mainly composed of saturated and branched fatty acids, monounsaturated fatty acids, polyunsaturated fatty acids, cyclopropane fatty acids, and fatty acid methyl esters (Fig. 3 and Table 2). The fifteen PLFA compounds were widely detected in samples over the whole soil profile. These are i15:0, a15:0, n15:0, i16:0, n16:0, 10me16:0, i17:0, a17:0, cyc17:0,

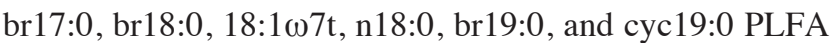
which account for $73.9-90.5 \%$ of the total PLFA. The other 12 PLFA compounds, most of which are the homologs of 16:1 and 18:1 PLFA, constitute no more than 5\% of total PLFA. Those compounds are only detected in some parts of the soil profile. For example, the 18:2w6 PLFA occurs only within a depth of $10 \mathrm{~cm}$. Both the cyc19:0 and n16:0 PLFA are the most abundant compounds in the sample set, the content of each being $13.19-21.07 \%$ and $11.2-17.3 \%$, respectively. The i15:0, 10me16:0, and i16:0 PLFA are also abundant in the soil, accounting for $7.54-10.93 \%, 3.38$ $10.36 \%$, and $4.24-5.66 \%$, respectively, of the total PLFA content (Table 1).

It is well known that the saturated and branched chain fatty acids, such as i15:0, a15:0, i17:0, a17:0, br17:0, and br18:0, are usually indicative of the presence of Grampositive bacteria (Lechevalier and Moss 1977; Sittig and Schlesner 1993; Zelles et al. 1997; Zhang et al. 2003), while the monounsaturated fatty acids and cyclopropyl fatty acids, such as $16: 1 \omega 7,16: 1 \omega 5,17: 1 \omega 11,17: 1 \omega 13$, cyc17:0,


membrane of Gram-negative bacteria (Taylor and Parkes 


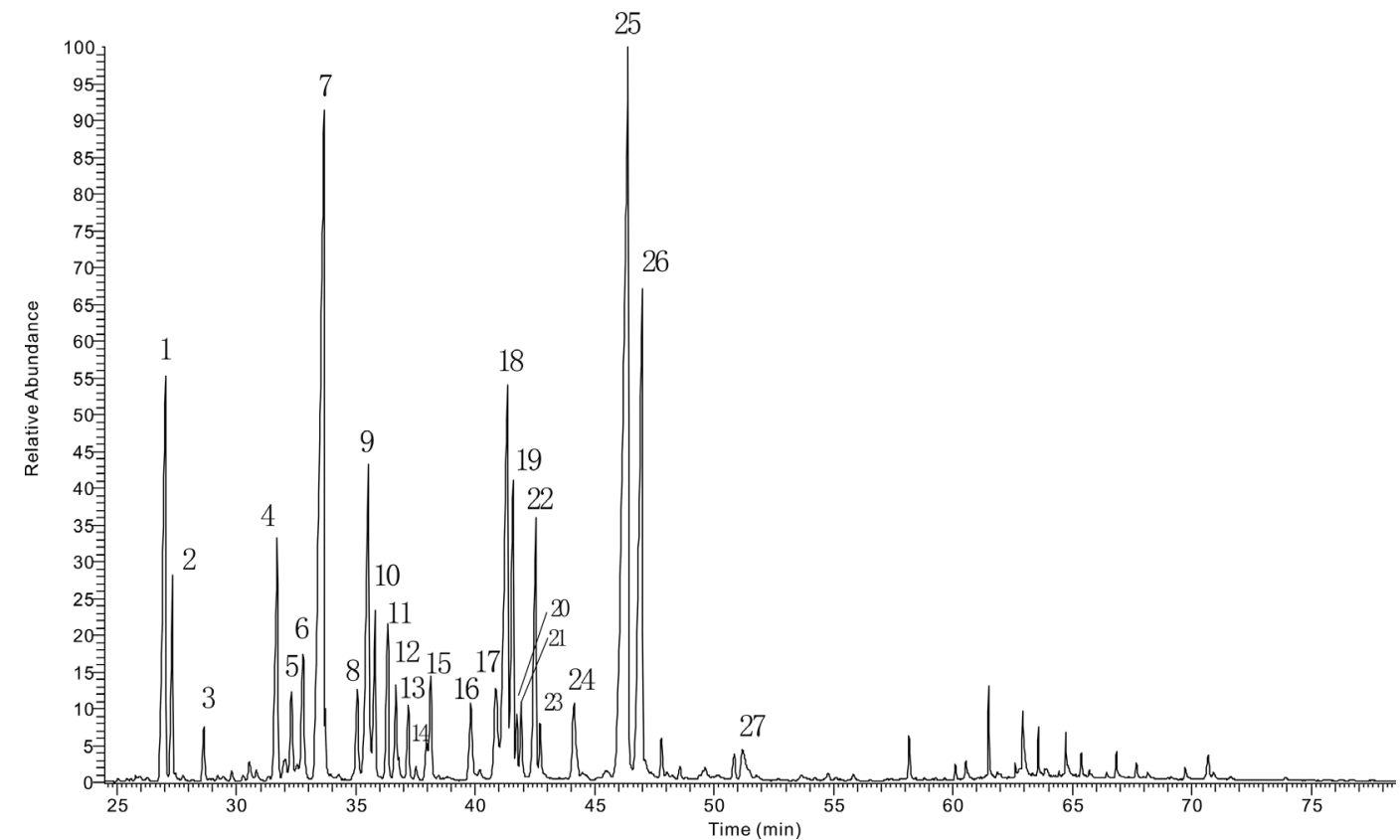

Fig. 3. The typical gas chromatogram showing the distribution of PLFA in soil samples from the Dinghushan Biosphere Preserve. Peak numbers are identified in Table 2.

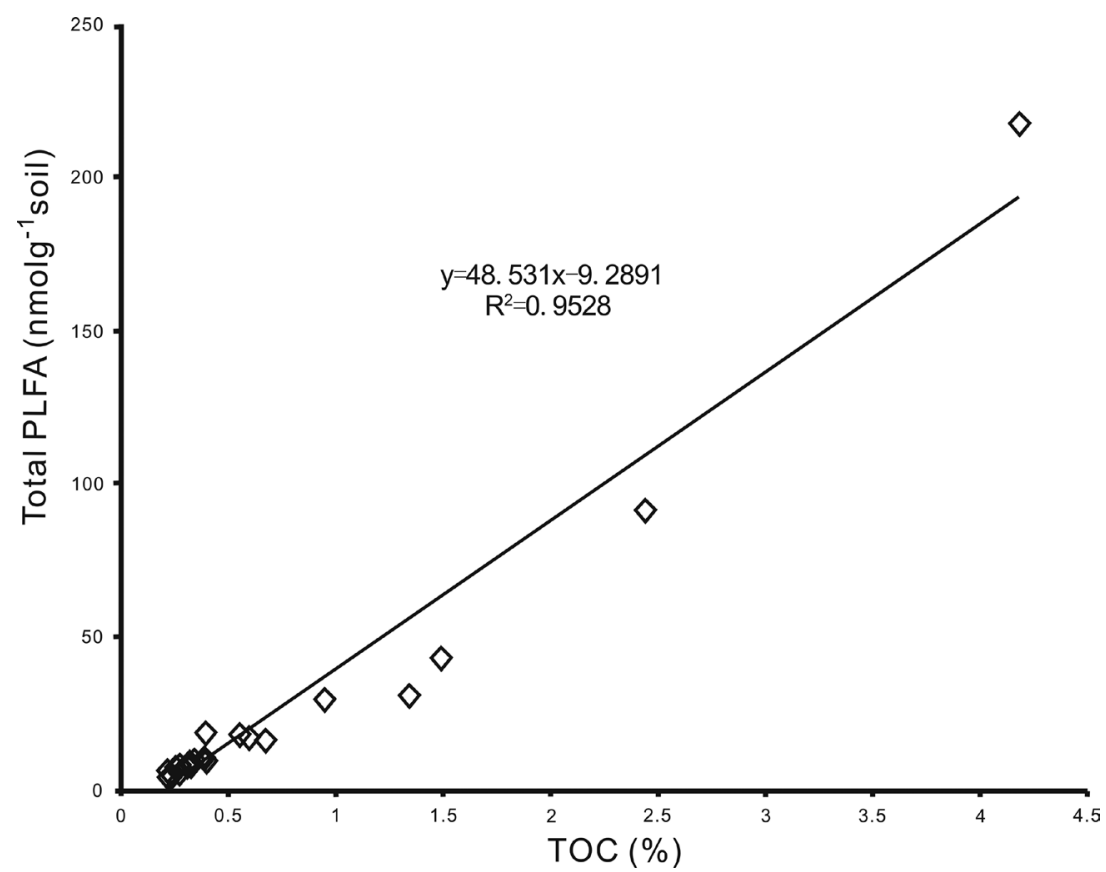

Fig. 4. The correlation between total PLFA concentrations and TOC within the soil profile from the Dinghushan Biosphere Preserve. 
Table 2. The FAME compounds identified in soil samples.

\begin{tabular}{c|cc}
\hline Peak No. & \multicolumn{2}{c}{ Compounds } \\
\hline 1 & i15:0 & 2-methyltetradecanoic methyl ester \\
2 & a15:0 & 3-methyltetradecanoic methyl ester \\
3 & n15:0 & n-pentadecanoic acid methyl ester \\
4 & i16:0 & 2-methylpentadecanoic methyl ester \\
5 & $16: 1 \omega 7 \mathrm{t}$ & trans-7-hexadecenoic methyl ester \\
6 & $16: 1 \omega 9 \mathrm{t}$ & trans-9-hexadecenoic methyl ester \\
7 & n16:0 & n-hexadecanoic acid methyl ester \\
8 & br17:0 & Methylhexadecanoic methyl ester \\
9 & 10 me16:0 & 10-methylhexadecanoic methyl ester \\
10 & br17:0 & Methylhexadecanoic methyl ester \\
11 & i17:0 & 2-methylhexadecanoic methyl ester \\
12 & a17:0 & 3-methylhexadecanoic methyl ester \\
13 & cyc17:0 & 9, 10-methylenehexadecanoic methyl ester \\
14 & n17:0 & n-heptadecanoic acid methyl ester \\
15 & br18:0 & Methylheptadecanoic methyl ester \\
16 & br18:0 & Methylheptadecanoic methyl ester \\
17 & $18: 2 \omega 6$ & 6-octadecadienoic methyl ester \\
18 & $18: 1 \omega 9 \mathrm{c}$ & cis-9-octadecenoic methyl ester \\
19 & $18: 1 \omega 7 \mathrm{c}$ & cis-7-octadecenoic methyl ester \\
20 & $18: 1 \omega 7 \mathrm{t}$ & trans-7-octadecenoic methyl ester \\
21 & $18: 1 \omega 5 \mathrm{c}$ & cis-5-octadecenoic methyl ester \\
22 & $\mathrm{n} 18: 0$ & n-octadecanoic acid methyl ester \\
23 & br19:1 & Methylnonadecyenoic methyl ester \\
24 & br19:0 & Methylnonadecanoic methyl ester \\
25 & cyc19:0 & 11, 12-methyleneoctadecanoic methyl ester \\
26 & STD & n-nonadecanoic acid methyl ester \\
\hline & $>20: 0$ & Saturated straight chain longer than 20C atoms \\
\hline & &
\end{tabular}

1983; Helmke and Weyland 1984; Coleman et al. 1993; Schouten et al. 2004). As shown in Fig. 5, except for the soil samples from the upper $10 \mathrm{~cm}$, the relative concentration of saturated and branched PLFA within the soil profile reaches up to $70-80 \%$ of total PLFA content. Even if soils from the upper $10 \mathrm{~cm}$ are considered, there is still abundant saturated and branched PLFA with a 60 - 65\% of total PLFA content. The molecular distributions of PLFA strongly indicate that the Gram-negative bacteria rapidly decrease, and the Grampositive bacteria have a dominant position in soil microbial populations at the Wukesong site, Dinghushan Biosphere Preserve. Microbial carbon source had a great influence on soil microbial life activities, and the change of carbon source could lead to the change of relative content of Gram-negative bacteria and Gram-positive bacteria in the community structure. Kramer found that Gram-negative bacteria tended to utilize fresh plants as carbon sources, whereas Gram-positive bacteria could better utilize recalcitrant organic matter
(Griffiths et al. 1998; Kramer and Gleixner 2008). In this research, Gram-negative bacteria are predominant in the top $10 \mathrm{~cm}$ section, which is related to the fact that a large number of fresh plant litter inputs are present on the surface soil. A rise in the depth of Gram-positive bacteria and a decrease in negative bacteria indicate that the lack of fresh carbon sources below the $10 \mathrm{~cm}$, so Gram-positive bacteria, which can better utilize hard-degradable organic matter, are more abundant than Gram-negative bacteria.

In addition, the proportion of 16:1 and 18:1 homologues as well as 18:2 $\omega 6$ were lower in the Wukesong soil profile, and neither of them could be detected below $10 \mathrm{~cm}$. 16:1 107 and 18:1 107 are more prevalent in aerobic bacteria, normally found in methane oxidizing bacteria in symbiosis with peat moss (methanotrophs) (Dedysh et al. 2004; Chen et al. 2005; Van Winden et al. 2010). In view of the $\mathrm{CH}_{4}$ flux average value $\left(-44.6 \pm 5.79 \mu \mathrm{g} \mathrm{m}^{-2} \mathrm{~h}^{-1}\right)$ in Dinghushan Wukesong broad forest (Zhou et al. 2005), it could be inferred that methanogenic bacteria contribute to the $16: 1 \omega 7$ and $18: 1 \omega 7$ of the top $10 \mathrm{~cm}$ layer in the soil profile. As the oxygen content in deep soil is lower, the activity of soil microbes shifted from the aerobic process to the anaerobic process, and the methane oxidizing bacteria were inhibited and the activity of methanogenic bacteria decreased (Zhou et al. 2005). The fact that methanotrophic bacteria disappeared below $10 \mathrm{~cm}$ indicated that the activities of some of the microorganisms are inhibited, from which we infer that the available carbon source and oxygen content of micro environment may be reduced. 18:2 $\omega 6$, as a fungal specific PLFA that can indicate the biomass of fungi (Zelles 1999), disappeared below $10 \mathrm{~cm}$, and indicated that the oxygen content of the micro environment may be reduced.

\subsection{Determination of the Soil Anaerobic Zone at the Wukesong Soil Profile from the Dinghushan Biosphere Preserve}

It is well known that all of the litter quality, nutrient conditions, soil characteristics, temperature, soil wet-dry cycle, $\mathrm{pH}$ value of the soil, nitrogen deposition, acid rain, increase in $\mathrm{CO}_{2}$ content and other changes in the environmental conditions have effects on the cycle of soil carbon (Clein and Schimel 1994; Motavalli et al. 1995; Six et al. 1999; Giardina and Ryan 2000; Hobbie and Vitousek 2000; Krajick 2001). These factors will affect the composition and activity of microbial communities in the soil, suggesting that the microbial communities can be a good indicator to decipher the condition of the whole living environment of soil and probe the mechanisms on the decomposition and accumulation of the soil organic matter (Giardina and Ryan 2000). As discussed earlier, 10me16:0 was considered to be an indicator for anaerobic processes having taken place in the soil. The microbial community structure in the forest soil profile from the Dinghushan Biosphere Preserve showed 


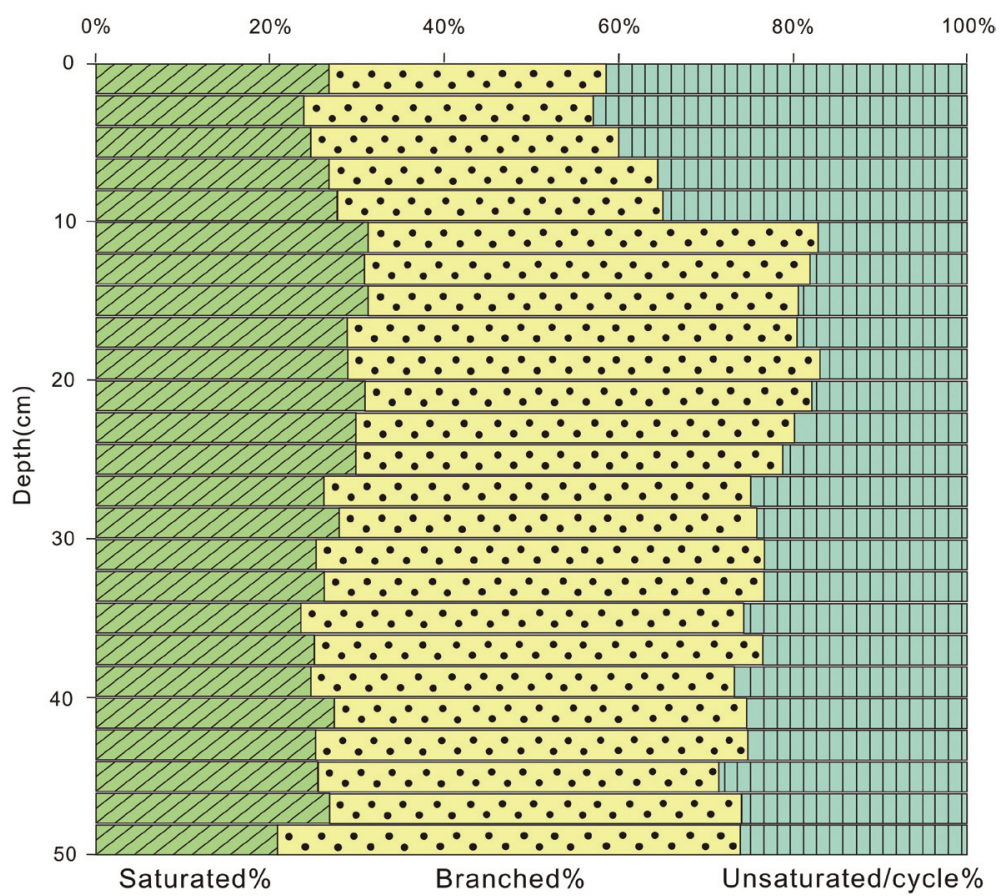

Fig. 5. The relative concentrations of saturated PLFA, branched PLFA, and unsaturated/cyclic PLFA upon soil profile from the Dinghushan Biosphere Preserve.

that the 10me16:0 PLFA has relatively high abundances with a $3.38-10.36 \%$ of total PLFA content (Table 1).

There are at least three possible sources for 10me16:0 PLFA in soil environments. Actinomycetes, which are particularly abundant in soils, produce 10me16:0 (Kroppenstedt 1985) and may be the source of this PLFA. Several studies have detected actinomycetes in various environments (Helmke and Weyland 1984; Jensen et al. 1991; Mincer et al. 2002). However, 10me17:0 and 10me18:0 are always produced in equal or greater amounts than 10me16:0 PLFA by actinomycetes (Bousfield et al. 1983; Kroppenstedt 1985), and these compounds were not detected in our samples. Therefore, actinomycetes are unlikely to be the main source of 10me16:0 PLFA in the soil profile of Wukesong, Dinghushan Biosphere Preserve.

Another possible source of 10me16:0 in soil environments is the phylum Planctomycetes. The 10me16:0 PLFA was normally detected at a concentration level of 8.1 and $3.6 \%$ of the total PLFA content of Planctomyces maris and a planctomycete-like bacterium, respectively (Sittig and Schlesner 1993), and has also been detected in Candidatus 'Brocadia anammoxidans' and Candidatus 'Kuenenia stuttgartiensis', both of which are anaerobic ammonium-oxidizing (anammox) planctomycetes (Sinninghe Damsté et al. 2002). Previous study showed that the autotrophic metabolism of anammox bacteria can result in PLFA becoming depleted by up to $42 \%$ with respect to a $\mathrm{CO}_{2(\mathrm{~g})}$ carbon source (Schouten et al. 2004). Therefore, anammox bacteria could be theoretically producing 10me16:0 PLFA with a $\delta^{13} \mathrm{C}$ value as negative as $-52 \%$. However, this is not the case of stable carbon isotope data measured in this study, and the anammox bacteria are therefore not a possible source of the 10me16:0 PLFA detected in the soil profile from the Wukesong, Dinghushan Biosphere Preserve.

However, the 10me16:0 PLFA has often been used as a bioindicator for the genus Desulfobacter of Sulfate-reducing bacteria (SRB) in various environments (Taylor and Parkes 1983; Vainshtein et al. 1992; Londry et al. 2004). It is known that the 10me16:0 PLFA is produced in significant amounts by several Desulfobacter species and the closely related Desulfobacterium autotrophicum. The most important fact is that these organisms also produce a significant amount of cyc17:0 in addition to 10me16:0 PLFA (Coleman et al. 1993; Rajendran et al. 1993). This is exactly the same as what we discovered in the studied soil samples from the Dinghushan Biosphere Preserve, which complicates the source identification of 10me16:0 PLFA (Table 3).

In the SRB cell, cyc17:0 and 10me16:0 PLFA both result from the 16:107 PLFA via donation of a methyl group from $S$-adenosyl- - -methionine (Zhang et al. 2003). Initially, SRB commonly assimilate the fatty acids of $\mathrm{C}_{3}, \mathrm{C}_{4}$ plants, volatile fatty acids, alcohols, etc., and the assimilation of substrates with low molecular weight can cause greater isotopic fractionation (> 20\%o). Then, stable carbon isotope fractionation associated with lipid biosynthesis occurs again during the formation of acetyl-CoA, which is the precursor for fatty acid biosynthesis. Finally, the ${ }^{13} \mathrm{C}$-depleted methyl group from $S$-adenosyl- ${ }_{\mathrm{L}}$-methionine causes the more 
Table 3. The $\delta^{13} \mathrm{C}$ values of PLFA in soil samples (\%oVPDB).

\begin{tabular}{|c|c|c|c|c|c|}
\hline Depth (cm) & i15:0 & i16:0 & n16:0 & 10me16:0 & n18:0 \\
\hline $0-2$ & -25.4 & -27.2 & -25.5 & -28 & -28.3 \\
\hline $2-4$ & -24.8 & -25.7 & -24.6 & -27.3 & -26.4 \\
\hline $4-6$ & -24.7 & -23.1 & -23.4 & -26.2 & -25.9 \\
\hline $6-8$ & -24.9 & -22.9 & -23.2 & -25 & -22.6 \\
\hline $8-10$ & -24.2 & -21.7 & -22.8 & -25 & -23.6 \\
\hline $10-12$ & -23.1 & -21.2 & -23.3 & -22.7 & -22.5 \\
\hline $12-14$ & -23.7 & -22.3 & -24.4 & -23.7 & -23.5 \\
\hline $14-16$ & -23.9 & -22.8 & -24.9 & -25.5 & -24.3 \\
\hline $16-18$ & -23.9 & -22.9 & -24.6 & -24.9 & -23.8 \\
\hline $18-20$ & -23.4 & -23.3 & -25.9 & -27.3 & -23.7 \\
\hline $20-22$ & -24.1 & -23.4 & -25.7 & -26.8 & -24.2 \\
\hline $22-24$ & -24.1 & -22.7 & -25.4 & -26.5 & -24.2 \\
\hline $24-26$ & -23.9 & -22.9 & -24.8 & -25.5 & -23.6 \\
\hline $26-28$ & -23.8 & -22.7 & -24.5 & -26 & -22.9 \\
\hline $28-30$ & -23.5 & -23.2 & -25.3 & -26.9 & -26.2 \\
\hline $30-32$ & -24.8 & -23.9 & -26.3 & -27.7 & -25.1 \\
\hline $32-34$ & -25.2 & -24.4 & -26.6 & -28.1 & -25.7 \\
\hline $34-36$ & -24.7 & -24.5 & -26.7 & -28.1 & -27.5 \\
\hline $36-38$ & -24.8 & -24 & -26.2 & -27.2 & -25.5 \\
\hline $38-40$ & -24.6 & -23.9 & -25.8 & -27 & -26.2 \\
\hline $40-42$ & -24.4 & -23.8 & -25.8 & -26.8 & -25.5 \\
\hline $42-44$ & -24.7 & -23.8 & -25.9 & -26.7 & -25.3 \\
\hline $44-46$ & -24.8 & -24.2 & -26.1 & -26.9 & -25.7 \\
\hline $46-48$ & -24.8 & -23.9 & -26.3 & -26.9 & -25.5 \\
\hline $48-50$ & -24.8 & -24 & -26.3 & -27.5 & -25.4 \\
\hline
\end{tabular}

negative $\delta^{13} \mathrm{C}$ values of $10 \mathrm{me} 16: 0$ and cyc17:0 PLFA (Zhang et al. 2003). As shown in Fig. 6, the $\delta^{13} \mathrm{C}$ values of 10me16:0 PLFA is lighter those of other PLFAs in soil profile, indicating that at least some of the 10me16:0 PLFA originates from a particular carbon source or living organisms with specific metabolic reactions. Together with molecular distributions of PLFA, the special biosynthetic pathway used by SRB probably plays a key role in terms of the processes involved in the formation of 10me16:0 PLFA.

Figure 7 shows the concentration profiles of 10me16:0 and cyc17:0 PLFA with depth. In the upper $10 \mathrm{~cm}$ of the soil profile, the ratio of cyc17:0/(cyc17:0 + 10me16:0) shows a little increase possibly induced by multiple source at the topsoil layer, where the microorganism usually has strong activity and is well developed due to large quantities input of organic matter. It suggests that the SRB is not the only source of 10me16:0 and/or cyc17:0 in the topsoil layer until below $10 \mathrm{~cm}$. In the depth, the ratio almost remains stable, suggesting that cyc17:0 and 10me16:0 PLFAs are derived from a stable community of microorganism. The sulfatereducing bacteria are the best candidates and the co-occur- rence of these two PLFA can be a marker of the development of SRB at the $10 \mathrm{~cm}$ depth.

The SRB can survive an environment with the oxygen concentration as high as $4.5 \mathrm{mg} \mathrm{L}^{-1}$ and stops growing when the oxygen concentration rises to $9.0 \mathrm{mg} \mathrm{L}^{-1}$ (Devereux et al. 1989; Taylor and Parkes 1983) because the sulfate reduction reaction must occur at a relatively low oxidation-reduction potential. The molecular distributions and stable carbon isotopic compositions of PLFAs from the Wukesong soil profile clearly demonstrate that the significant development of SRB occurs in the top $10 \mathrm{~cm}$, indicating the occurrence of a transition zone from high-oxygen-concentration environment to low-oxygen-concentration environment, further marking the position of the anaerobic zone in the soil profile.

\subsection{Factors Controlling the SRB Occurrence at the Wukesong Soil Profile and Implication for the Soil Organic Carbon Accumulation}

Free oxygen in the soil system has important effects on the viability of microbes and determines the kinetics at 
which the organic carbon can be decomposed by microbes, especially on the control of development of SRB. From Table 1, the $\mathrm{pH}$ value of soil in the upper $0-14 \mathrm{~cm}$ part of profile has the biggest change, from 3.06 - 3.66, and then a little decreased, down to $3.40(18 \mathrm{~cm})$. Then, with the increase of depth, the $\mathrm{pH}$ value increases slowly until the $\mathrm{pH}$ value is 3.74 . Generally, the $\mathrm{pH}$ value below $14 \mathrm{~cm}$ changes very little. The Wukesong region has very high biomass, the annual decomposition of which produces many organic ac- ids, which may cause natural acidification (Liu et al. 2010; Huang et al. 2014; Zhu et al. 2016). Moreover, it cannot be ignored that the Dinghushan Biosphere Preserve is located in a low-latitude south subtropical monsoon climate region. In last three decades, acid rain has become one of the main environmental issues due to heavy pollution induced by the rapid regional economic development. The natural soil acidification, plus the influence of external natural acid deposition in promoting soil acidification, cause the lower $\mathrm{pH}$

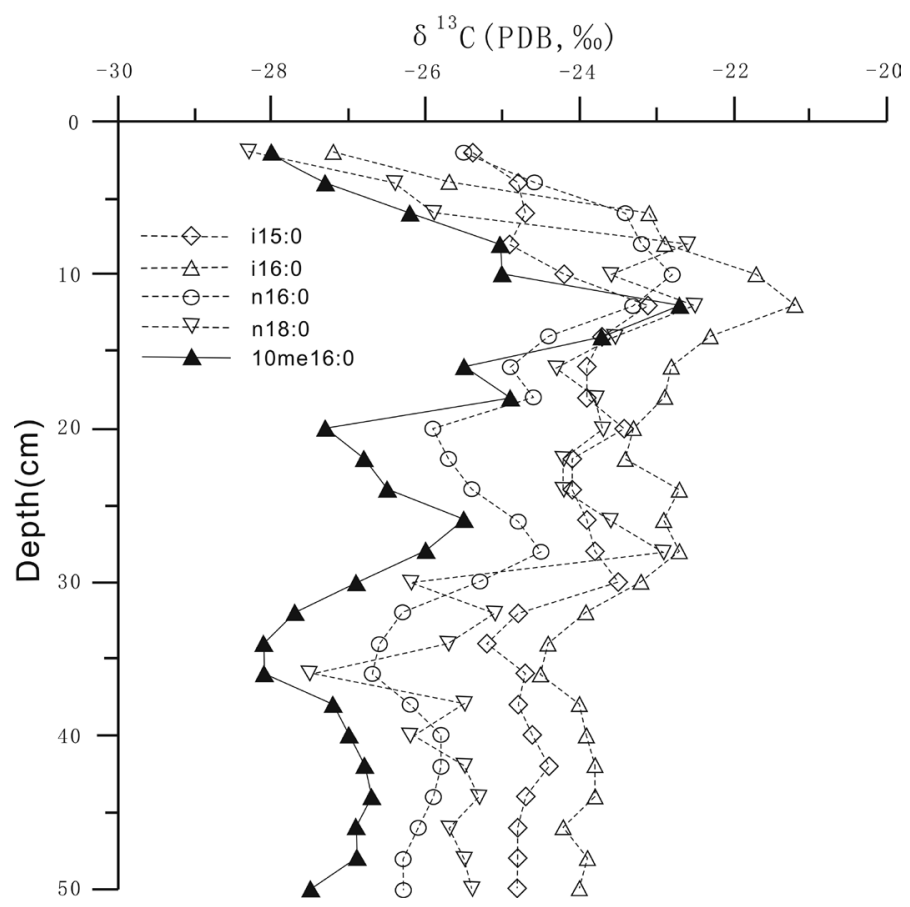

Fig. 6. The stable carbon isotopic compositions of PLFA within the soil profile from the Dinghushan Biosphere Preserve.
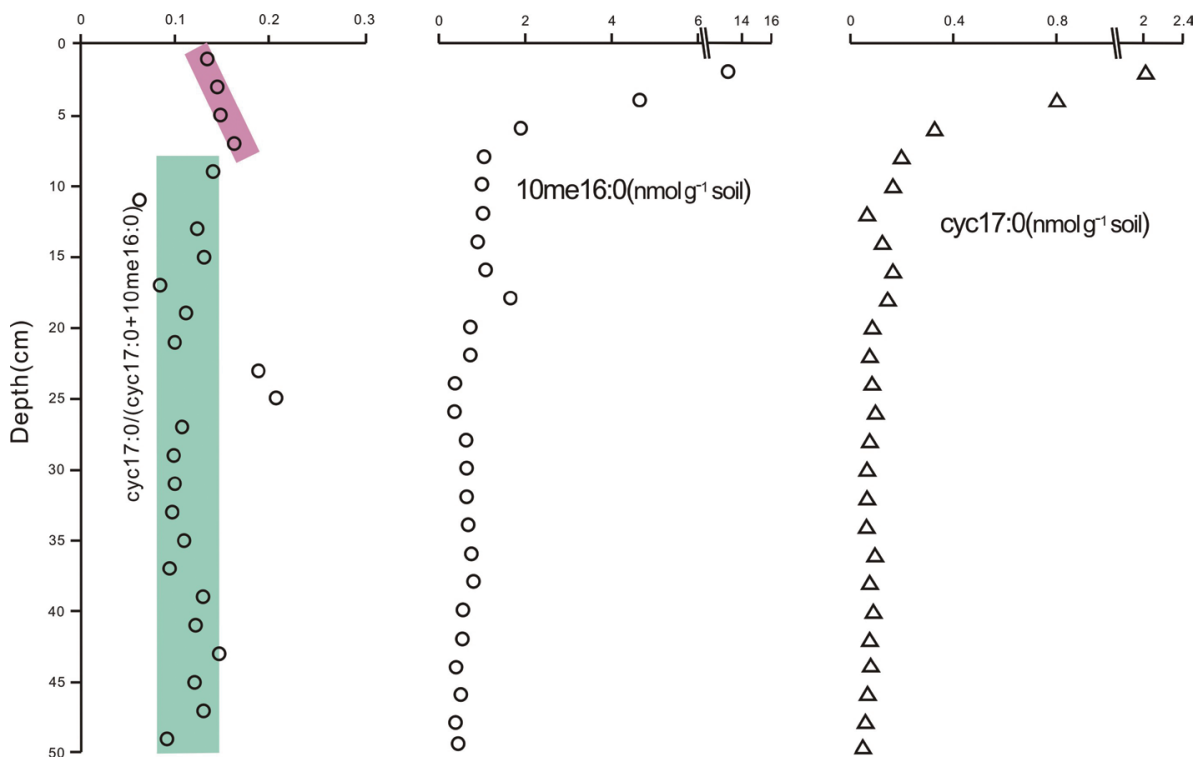

Fig. 7. The relationship between 10me16:0 and cyc17:0 PLFA within the soil profile from the Dinghushan Biosphere Preserve. 
value (Liu et al. 2010). Liu et al. (2010) made a long-term record of soil $\mathrm{pH}$ value in the Dinghushan Biosphere preserve. The result clearly demonstrates that the Dinghushan mineral soil $\mathrm{pH}$ at $0-20 \mathrm{~cm}$ depth declined significantly from $4.75-4.60$ in 1980 s to $4.02-3.84$ in 2005 , and the rapid increase of soil $\mathrm{pH}$ was most attributed to long-term high atmospheric acid deposition. Physicochemical reactions induced by acid rain in the soil system make the soil structure lose its mechanical strength gradually, resulting in cracking, mass loss, structural failure, and decreases of soil porosity if there is prolonged acid deposition (Fan et al. 2010). Thereafter, the oxygen concentration in the soil system will be decreased, forming anaerobic environments that are favorable for SRB. We deduced that the shallow depth (the top $10 \mathrm{~cm}$ in this study) of the soil anaerobic zone at the Wukesong soil profile from the Dinghushan Biosphere Preserve could be mainly the result of the acid rain environment, because the soil anaerobic zone is normally thought to occur at a depth of approximately $20-30 \mathrm{~cm}$. The rise of the anaerobic zone favors the preservation of the organic matter in the soil. On the other hand, acid rain can reduce the rate of litter decomposition by altering the chemical and biological processes of forest soil and primarily decreasing soil $\mathrm{pH}$ values (Hutchinson and Davis 1980; Neuvonen and Suomela 1990; Dangles et al. 2004), although there was a report that acid rain can accelerate the rate of litter decomposition by laboratory simulation experiments (Lee and Weber 1983). The results suggest that microbial ecosystem change due to acid rain results in the change of the structure and activity of microbial communities in soil profile. Although the increase of SOC stock is attributed to numerous factors including: increase in the amount of biomass (above- and below-ground) returned to the soil, change in soil moisture and temperature regimes which accentuate the rate of decomposition of organic matter, low decomposability of litter residues due to differences in $\mathrm{C}: \mathrm{N}$ ratio and lignin content, increase in soil aggregation and raise in physical protection of the soil organic matter (Larionova et al. 2002), the decreasing rate of litter decomposition in topsoil layer, together with the rise of the depth of the anaerobic zone, may play key roles on the carbon accumulation in the depth of $0-20 \mathrm{~cm}$ in the soil profile from the Dinghushan Biosphere Preserve (Zhou et al. 2006).

\section{CONCLUSION}

The phospholipid ester-linked fatty acids (PLFA) detected in soil from the Wukesong in the Dinghushan Biosphere Preserve are mostly derived from microorganisms. The soil microbial biomass represented by the total concentration of PLFA is positively correlated to TOC content, indicating that the activity of the microbes within the soil profile is significantly controlled by the input of organic matter. Two SRB-derived PLFA from Desulfobacter and
Desulfobacterium autotrophicum, 10me16:0 and cyc17:0, are identified by molecular and stable carbon isotopic methods. Moreover, methanotrophic bacteria, fungi, the Gramnegative bacteria, the gram-positive bacteria are all identified. That SRB occurs in the top $10 \mathrm{~cm}$, methanotrophic bacteria and fungi disappeared below $10 \mathrm{~cm}$, and the gramnegative bacteria are reduced, with gram-positive bacteria dominating at that depth; all of which indicated that the activities of some of the microorganisms are inhibited, from which we infer that the available carbon source and oxygen content of the micro environment may be reduced below the top $10 \mathrm{~cm}$ of the profile. The shallow depth (top $10 \mathrm{~cm}$ ) of the soil anaerobic zone at the Wukesong soil profile is considered to be mainly associated with the local environment of severe acid rain. The physicochemical reactions induced by acid rain in the soil system result in a decrease of soil porosity, and consequently, a decreased porosity-dependent oxygen concentration. Although the increase of soil organic carbon stock is attributed to numerous factors, the reduced rate of litter decomposition in the topsoil layer due to the acid rain environment, together with the rise of the depth of the anaerobic zone, may play substantial roles in the carbon accumulation in the depth of $0-20 \mathrm{~cm}$ in the soil profile from the Dinghushan Biosphere Preserve.

Acknowledgements We would like to express our thanks to Drs. Wanglu Jia and Tongshou Xiang of SKLOG for their technical assistance during the GC-MS and GC-IR-MS analyses. This work was supported by the grants from NSFC (Grant No. 41303067), NSFZJ (Grant No. R5080124) and the Fundamental Research Funds for the Central Universities.

\section{REFERENCES}

Abraham, W. R., C. Hesse, and O. Pelz, 1998: Ratios of carbon isotopes in microbial lipids as an indicator of substrate usage. Appl. Environ. Microbiol., 64, 42024209.

Ågren, G. I., E. Bosatta, and J. Balesdent, 1996: Isotope discrimination during decomposition of organic matter: A theoretical analysis. Soil Sci. Soc. Am. J., 60, 1121-1126, doi: 10.2136/sssaj1996.036159950060000 40023x. [Link]

Amann, R. I., W. Ludwig, and K.-H. Schleifer, 1995: Phylogenetic identification and in situ detection of individual microbial cells without cultivation. Microbiological reviews, 59, 143-169.

Baird, B. H. and D. C. White, 1985: Biomass and community structure of the abyssal microbiota determined from the ester-linked phospholipids recovered from Venezuela Basin and Puerto Rico Trench sediments. Mar. Geol., 68, 217-231, doi: 10.1016/0025-3227(85)900131. [Link]

Baird, B. H., D. E. Nivens, J. H. Parker, and D. C. White, 
1985: The biomass, community structure, and spatial distribution of the sedimentary microbiota from a high-energy area of the deep sea. Deep-Sea Res. Part I-Oceanogr. Res. Pap., 32, 1089-1099, doi: 10.1016/0198-0149(85)90064-0. [Link]

Balesdent, J., C. Girardin, and A. Mariotti, 1993: Siterelated $\delta^{13} \mathrm{C}$ of tree leaves and soil organic matter in a temperate forest. Ecology, 74, 1713-1721, doi: 10.2307/1939930. [Link]

Balkwill, D. L., F. R. Leach, J. T. Wilson, J. F. McNabb, and D. C. White, 1988: Equivalence of microbial biomass measures based on membrane lipid and cell wall components, adenosine triphosphate, and direct counts in subsurface aquifer sediments. Microb. Ecol., 16, 7384, doi: 10.1007/bf02097406. [Link]

Bazzaz, F., 1990: The response of natural ecosystems to the rising global $\mathrm{CO}_{2}$ levels. Annu. Rev. Ecol. Systemat., 21, 167-196, doi: 10.1146/annurev.ecolsys.21.1.167. [Link]

Bligh, E. G. and W. J. Dyer, 1959: A rapid method of total lipid extraction and purification. Can. J. Biochem. Physiol., 37, 911-917, doi: 10.1139/o59-099. [Link]

Boschker, H. T. S., S. C. Nold, P. Wellsbury, D. Bos, W. de Graaf, R. Pel, R. J. Parkes, and T.E. Cappenberg, 1998: Direct linking of microbial populations to specific biogeochemical processes by ${ }^{13} \mathrm{C}$-labelling of biomarkers. Nature, 392, 801-805, doi: 10.1038/33900. [Link]

Boschker, H. T. S., J. F. C. de Brouwer, and T. E. Cappenberg, 1999: The contribution of macrophyte-derived organic matter to microbial biomass in salt-marsh sediments: Stable carbon isotope analysis of microbial biomarkers. Limnol. Oceanogr., 44, 309-319, doi: 10.4319/lo.1999.44.2.0309. [Link]

Bousfield, I. J., G. L. Smith, T. R. Dando, and G. Hobbs, 1983: Numerical analysis of total fatty acid profiles in the identification of Coryneform, Nocardioform and some other bacteria. Microbiology, 129, 375-394, doi: 10.1099/00221287-129-2-375. [Link]

Budge, K., J. Leifeld, M. Egli, and J. Fuhrer, 2011: Soil microbial communities in (sub)alpine grasslands indicate a moderate shift towards new environmental conditions 11 years after soil translocation. Soil Biol. Biochem., 43, 1148-1154, doi: 10.1016/j.soilbio.2011.02.001. [Link]

Castellazzi, M. S., P. C. Brookes, and D. S. Jenkinson, 2004: Distribution of microbial biomass down soil profiles under regenerating woodland. Soil Biol. Biochem., 36, 1485-1489, doi: 10.1016/j.soilbio.2004.04.020. [Link]

Chen, Q., C. Shen, Y. Sun, S. Peng, W. Yi, Z. Li, and M. Jiang, 2005: Mechanism of distribution of soil organic matter with depth due to evolution of soil profiles at the Dinghushan Biosphere Reserve. Acta Pedologica Sinica, 42, 1-8.

Clein, J. S. and J. P. Schimel, 1994: Reduction in microbial activity in Birch litter due to drying and rewetting event. Soil Biol. Biochem., 26, 403-406, doi: 10.1016/00380717(94)90290-9. [Link]

Coleman, M. L., D. B. Hedrick, D. R. Lovley, D. C. White, and K. Pye, 1993: Reduction of Fe(III) in sediments by sulphate-reducing bacteria. Nature, 361, 436-438, doi: 10.1038/361436a0. [Link]

Dangles, O., M. O. Gessner, F. Guerold, and E. Chauvet, 2004: Impacts of stream acidification on litter breakdown: implications for assessing ecosystem functioning. J. Appl. Ecol., 41, 365-378, doi: 10.1111/j.00218901.2004.00888.x. [Link]

Dedysh, S. N., Y. Y. Berestovskaya, L. V. Vasylieva, S. E. Belova, V. N. Khmelenina, N. E. Suzina, Y. A. Trotsenko, W. Liesack, G. A. Zavarzin, 2004: Methylocella tundrae sp. nov., a novel methanotrophic bacterium from acidic tundra peatlands. Int. J. Syst. Evol. Microbiol., 54, 151-156, doi: 10.1099/ijs.0.02805-0. [Link]

Devereux, R., M. Delaney, F. Widdel, and D. A. Stahl, 1989: Natural relationships among sulfate-reducing eubacteria.J.Bacteriol., 171, 6689-6695, doi: 10.1128/ jb.171.12.6689-6695.1989. [Link]

Eswaran, H., E. Van Den Berg, and P. Reich, 1993: Organic carbon in soils of the world. Soil Sci. Soc. Am. J., 57, 192-194, doi: 10.2136/sssaj1993.03615995005700010 034x. [Link]

Fan, Y. F., Z. Q. Hu, Y. Z. Zhang, and J. L. Liu, 2010: Deterioration of compressive property of concrete under simulated acid rain environment. Construct. Build.Mater., 24, 1975-1983, doi: 10.1016/j.conbuildmat.2010.04.002. [Link]

Fernandez, I. J., Y. Son, C. R. Kraske, L. E. Rustad, and M. B. David, 1993: Soil carbon dioxide characteristics under different forest types and after harvest. Soil Sci. Soc. Am. J., 57, 1115-1121, doi: 10.2136/sssaj1993.03 615995005700040039x. [Link]

Fierer, N., J. P. Schimel, and P. A. Holden, 2003: Variations in microbial community composition through two soil depth profiles. Soil Biol. Biochem., 35, 167-176, doi: 10.1016/s0038-0717(02)00251-1. [Link]

Findlay, R. D., H. W. Taeusch, and F. J. Walther, 1996: Surfactant replacement therapy for meconium aspiration syndrome. Pediatrics, 97, 48-52.

Franklin, R. B. and A. L. Mills, 2009: Importance of spatially structured environmental heterogeneity in controlling microbial community composition at small spatial scales in an agricultural field. Soil Biol. Biochem., 41, 1833-1840, doi: 10.1016/j.soilbio.2009.06.003. [Link]

Giardina, C. P. and M. G. Ryan, 2000: Evidence that decomposition rates of organic carbon in mineral soil do not vary with temperature. Nature, 404, 858-861, doi: 10.1038/35009076. [Link]

Griffiths, B. S., K. Ritz, N. Ebblewhite, and G. Dobson, 
1998: Soil microbial community structure: Effects of substrate loading rates. Soil Biol. Biochem., 31, 145153, doi: 10.1016/s0038-0717(98)00117-5. [Link]

Guan, B., 1989: World Forestry, China Forestry Publishing House, Beijing, 3-22.

Helmke, E. and H. Weyland, 1984: Rhodococcus marinonascens sp. nov., an Actinomycete from the Sea. Int. J. Syst. Bacteriol., 34, 127-138, doi: 10.1099/0020771334-2-127. [Link]

Hobbie, S. E. and P. M. Vitousek, 2000: Nutrient Limitation of Decomposition in Hawaiian Forests. Ecology, 81, 1867-1877, doi: 10.2307/177277. [Link]

Huang, J., J. Mo, W. Zhang, and X. Lu, 2014: Research on acidification in forest soil driven by atmospheric nitrogen deposition. Acta Ecologica Sinica, 34, 302-310, doi: 10.1016/j.chnaes.2014.10.002. [Link]

Hutchinson, T. C. and M. Davis, 1980: Effects of Acid Precipitation on Terrestrial Ecosystems, Plenum Press, New York, 372 pp.

Jenkinson, D. S. and J. H. Rayner, 1977: The turnover of soil organic matter in some of the Rothamsted classical experiments. Soil Sci., 125, 298-305, doi: 10.1097/00010694-197705000-00005. [Link]

Jensen, P. R., R. Dwight, and W. Fenical, 1991: Distribution of actinomycetes in near-shore tropical marine sediments. Appl. Environ. Microbiol., 57, 1102-1108.

Kaneda, T., 1967: Fatty acids in the genus Bacillus. I. Isoand anteiso-fatty acids as characteristic constituents of lipids in 10 species. J. Bacteriol., 93, 894-903.

Kanerva, T., A. Palojärvi, K. Rämö, and S. Manninen, 2008: Changes in soil microbial community structure under elevated tropospheric $\mathrm{O}_{3}$ and $\mathrm{CO}_{2}$. Soil Biol.Biochem., 40, 2502-2510, doi: 10.1016/j.soilbio.2008.06.007. [Link]

Koch, G. W. and H. A. Mooney, 1996: Response of terrestrial ecosystems to elevated $\mathrm{CO}_{2}$ : A synthesis and summary. Carbon Dioxide and Terrestrial Ecosystems, Academic Press, San Diego, 415-429, doi: 10.1016/ B978-012505295-5/50023-9. [Link]

Krajick, K., 2001: Long-term data show lingering effects from acid rain. Science, 292, 195-196, doi: 10.1126/ science.292.5515.195. [Link]

Kramer, C. and G. Gleixner, 2008: Soil organic matter in soil depth profiles: Distinct carbon preferences of microbial groups during carbon transformation. Soil Biol. Biochem., 40, 425-433, doi: 10.1016/j.soilbio.2007.09.016. [Link]

Kroppenstedt, R. M., 1985: Fatty acid and menaquinone analysis of actinomycetes and related organisms. In: Goodfellow, M. and D. E. Minnikin (Eds.), Chemical Methods in Bacterial Systematics, Elsevier Science \& Technology Books, London, UK, 173-199.

Larionova, A. A., L. N. Rozanova, I. V. Evdokimov, and A. M. Ermolaev, 2002: Carbon budget in natural and an- thropogenic forest-steppe ecosystems. Pochvovedenie, 2, 177-185.

Lechevalier, M. P. and C. W. Moss, 1977: Lipids in bacterial taxonomy - A taxonomist's view. CRC Critical Reviews in Microbiology, 5, 109-210, doi: 10.3109/10408417709102311. [Link]

Lee, J. J. and D. E. Weber, 1983: Effects of sulfuric acid rain on decomposition rate and chemical element content of hardwood leaf litter. Can. J. Bot., 61, 872-879, doi: 10.1139/b83-096. [Link]

Liu, K. H., Y. T. Fang, F. M. Yu, Q. Liu, F. R. Li, and S. L. Peng, 2010: Soil Acidification in Response to Acid Deposition in Three Subtropical Forests of Subtropical China. Pedosphere, 20, 399-408, doi: 10.1016/s10020160(10)60029-x. [Link]

Londry, K. L., L. L. Jahnke, and D. J. Des Marais, 2004: Stable Carbon Isotope Ratios of Lipid Biomarkers of Sulfate-Reducing Bacteria. Appl. Environ. Microbiol., 70, 745-751, doi: 10.1128/aem.70.2.745-751.2004. [Link]

Luyssaert, S., E.-D. Schulze, A. Börner, A. Knohl, D. Hessenmöller, B. E. Law, P. Ciais, and J. Grace, 2008: Old-growth forests as global carbon sinks. Nature, 455, 213-215, doi: 10.1038/nature07276. [Link]

McKinley, V. L., A. D. Peacock, and D. C. White, 2005: Microbial community PLFA and PHB responses to ecosystem restoration in tallgrass prairie soils. Soil Biol. Biochem., 37, 1946-1958, doi: 10.1016/j.soilbio.2005.02.033. [Link]

Mincer, T. J., P. R. Jensen, C. A. Kauffman, and W. Fenical, 2002: Widespread and persistent populations of a major new marine actinomycete taxon in ocean sediments. Appl. Environ. Microbiol., 68, 5005-5011, doi: 10.1128/AEM.68.10.5005-5011.2002. [Link]

Motavalli, P. P., C. A. Palm, W. J. Parton, E. T. Elliott, and S. D. Frey, 1995: Soil pH and organic C dynamics in tropical forest soils: Evidence from laboratory and simulation studies. Soil Biol.Biochem., 27, 1589-1599, doi: 10.1016/0038-0717(95)00082-p. [Link]

Neuvonen, S. and J. Suomela, 1990: The effect of simulated acid rain on pine needle and birch leaf litter decomposition. J.Appl.Ecol., 27, 857-872, doi: 10.2307/2404382. [Link]

Nguyen, L. M., M. P. Buttner, P. Cruz, S. D. Smith, and E. A. Robleto, 2011: Effects of elevated atmospheric $\mathrm{CO}_{2}$ on rhizosphere soil microbial communities in a Mojave Desert ecosystem. J. Arid Environ., 75, 917-925, doi: 10.1016/j.jaridenv.2011.04.028. [Link]

Paul, E. A. and F. E. Clark, 1996: Soil Microbiology and Biochemistry, Academic Press, San Diego, CA, USA, $340 \mathrm{pp}$.

Rajendran, N., O. Matsuda, and Y. Urushigawa, 1993: Microbial community structure in the sediments of Hiroshima Bay, Japan. Microbios, 75, 205-215.

Scharpenseel, H. W., P. Becker-Heidmann, H. U. Neue, and 
K. Tsutsuki, 1989: Bomb-carbon, ${ }^{14} \mathrm{C}$-dating and ${ }^{13} \mathrm{C}-$ Measurements as tracers of organic matter dynamics as well as of morphogenetic and turbation processes. Sci. Total Environ., 81-82, 99-110, doi: 10.1016/00489697(89)90115-0. [Link]

Schimel, D. S., J. I. House, K. A. Hibbard, P. Bousquet, P. Ciais, P. Peylin, B. H. Braswell, M. J. Apps, D. Baker, A. Bondeau, J. Canadell, G. Churkina, W. Cramer, A. S. Denning, C. B. Field, P. Friedlingstein, C. Goodale, M. Heimann, R. A. Houghton, J. M. Melillo, B. Moore, D. Murdiyarso, I. Noble, S. W. Pacala, I. C. Prentice, M. R. Raupach, P. J. Rayner, R. J. Scholes, W. L. Steffen, and C. Wirth, 2001: Recent patterns and mechanisms of carbon exchange by terrestrial ecosystems. Nature, 414, 169-172, doi: 10.1038/35102500. [Link]

Schouten, S., M. Strous, M. M. M. Kuypers, W. I. C. Rijpstra, M. Baas, C. J. Schubert, M. S. M. Jetten, and J. S. Sinninghe Damste, 2004: Stable carbon isotopic fractionations associated with inorganic carbon fixation by anaerobic ammonium-oxidizing bacteria. Appl. Environ. Microbiol., 70, 3785-3788, doi: 10.1128/ aem.70.6.3785-3788.2004. [Link]

Schutter, M. and R. Dick, 2001: Shifts in substrate utilization potential and structure of soil microbial communities in response to carbon substrates. Soil Biol. Biochem., 33, 1481-1491, doi: 10.1016/s0038-0717(01)00057-8. [Link]

Sinninghe Damsté, J. S., M. Strous, W. I. C. Rijpstra, E. C. Hopmans, J. A. J. Geenevasen, A. C. T. van Duin, L. A. van Niftrik, and M. S. M. Jetten, 2002: Linearly concatenated cyclobutane lipids form a dense bacterial membrane. Nature, 419, 708-712, doi: 10.1038/ nature01128. [Link]

Sittig, M. and H. Schlesner, 1993: Chemotaxonomic Investigation of Various Prosthecate and/or Budding Bacteria. Systematic and Applied Microbiology, 16, 92-103, doi: 10.1016/s0723-2020(11)80253-5. [Link]

Six, J., E. T. Elliott, and K. Paustian, 1999: Aggregate and soil organic matter dynamics under conventional and no-tillage systems. Soil Sci. Soc. Am. J., 63, 13501358, doi: 10.2136/sssaj1999.6351350x. [Link]

Stoeck, T., I. Kröncke, G. C. A. Duineveld, and A. Palojärvi, 2002: Phospholipid fatty acid profiles at depositional and non-depositional sites in the North Sea. Mar. Ecol. Prog. Ser., 241, 57-70, doi: 10.3354/meps241057. [Link]

Sun, Y., Z. Chen, S. Xu, and P. Cai, 2005: Stable carbon and hydrogen isotopic fractionation of individual n-alkanes accompanying biodegradation: Evidence from a group of progressively biodegraded oils. Org. Geochem., 36, 225-238, doi: 10.1016/j.orggeochem.2004.09.002. [Link]

Taylor, J. and R. J. Parkes, 1983: The cellular fatty acids of the sulphate-reducing bacteria, Desulfobacter sp., Desulfobulbus sp. and Desulfovibrio desulfuricans. Microbiology, 129, 3303-3309, doi: 10.1099/00221287-12911-3303. [Link]

Vainshtein, M., H. Hippe, and R. M. Kroppenstedt, 1992: Cellular fatty acid composition of Desulfovibrio species and its use in classification of sulfate-reducing bacteria. Systematic and Applied Microbiology, 15, 554566, doi: 10.1016/s0723-2020(11)80115-3. [Link]

Van Winden, J. F., N. Kip, G.-J. Reichart, M. S. M. Jetten, H. J. M. Op den Camp, and J. S. Sinninghe Damsté, 2010: Lipids of symbiotic methane-oxidizing bacteria in peat moss studied using stable carbon isotopic labelling. Org. Geochem., 41, 1040-1044, doi: 10.1016/j.orggeochem.2010.04.015. [Link]

Wang, Q., R. Wang, C. Tian, Y. Yu, Y. Zhang, and J. Dai, 2012: Using microbial community functioning as the complementary environmental condition indicator: A case study of an iron deposit tailing area. Eur. J. Soil Biol., 51, 22-29, doi: 10.1016/j.ejsobi.2012.03.004. [Link]

White, D. C., W. M. Davis, J. S. Nickels, J. D. King, and R. J. Bobbie, 1979: Determination of the sedimentary microbial biomass by extractible lipid phosphate. Oecologia , 40, 51-62, doi: 10.1007/bf00388810. [Link]

Zelles, L., 1999: Fatty acid patterns of phospholipids and lipopolysaccharides in the characterisation of microbial communities in soil: A review. Biol. Fertil. Soils, 29, 111-129, doi: 10.1007/s003740050533. [Link]

Zelles, L., A. Palojärvi, E. Kandeler, M. von Lützow, K. Winter, and Q. Y. Bai, 1997: Changes in soil microbial properties and phospholipid fatty acid fractions after chloroform fumigation. Soil Biol. Biochem., 29, 13251336, doi: 10.1016/S0038-0717(97)00062-X. [Link]

Zhang, C. L., Y. Li, Q. Ye, J. Fong, A. D. Peacock, E. Blunt, J. Fang, D. R. Lovley, and D. C. White, 2003: Carbon isotope signatures of fatty acids in Geobacter metallireducens and Shewanella algae. Chem. Geol., 195, 1728, doi: 10.1016/s0009-2541(02)00386-8. [Link]

Zhou, C., G. Zhou, Y. Wang, D. Zhang, S. Liu, and Y. Sun, 2005: $\mathrm{CH}_{4}$ fluxes from soil of coniferous broad-leaved mixed forest in Dinghu Mountain. Ecol. Environ., 14, 333-335, doi: 10.3969/j.issn.1674-5906.2005.03.010. [Link]

Zhou, G., S. Liu, Z. Li, D. Zhang, X. Tang, C. Zhou, J. Yan, and J. Mo, 2006: Old-growth forests can accumulate carbon in soils. Science, 314, 1417-1417, doi: 10.1126/ science.1130168. [Link]

Zhu, Q., W. De Vries, X. Liu, M. Zeng, T. Hao, E. Du, F. Zhang, and J. Shen, 2016: The contribution of atmospheric deposition and forest harvesting to forest soil acidification in China since 1980. Atmos. Environ., 146, 215-222, doi: 10.1016/j.atmosenv.2016.04.023. [Link] 